\title{
Decision Tree Algorithm In Analyzing The Incidence Of Neonatal Sepsis At Ulin Hospital Of Banjarmasin In 2016
}

\author{
Fitri Yuliana ${ }^{1 *}$ \\ ${ }^{1}$ Department of Diploma IV Midwifery Major in Teaching, STIKES Sari Mulia, Banjarmasin \\ *fitri_yuliana@stikessarimulia.ac.id \\ Novita Dewi Iswandari ${ }^{2}$ \\ ${ }^{2}$ Sari Mulia Midwifery Academy of Banjarmasin \\ novitadewiiswandari@yahoo.com \\ R.Topan Aditya Rahman ${ }^{2}$ \\ ${ }^{2}$ Sari Mulia Midwifery Academy of Banjarmasin \\ Topanaditya85@gmail.com
}

\begin{abstract}
Objective: To analyze the factors most related to the incidence of neonatal sepsis at Ulin Hospital of Banjarmasin in 2016

Method: This research used Rapid Miner simulation model with population of all newborns at Ulin Hospital of Banjarmasin in 2016 and the sample size was 210 infants consisting of 105 infants with neonatal sepsis and 105 infants without neonatal sepsis. The analysis used Algorithm C.45 (Decision Tree) to see the accuracy level, and Root Mean Squared Error.

Results: The factors most closely related with the incidence of neonatal sepsis were gestational age $\leq 33.5$ weeks with the strong power of relationship (0.643), accuracy rate of $80.95 \%$, and mean error rate of 0.401 .

Conclusion: Infants born with a gestational age $\leq 33.5$ weeks are at risk of having neonatal sepsis while those born with a gestation age $>33.5$ weeks are at risk when the born with asphyxia complication, birth weight $\leq 3875$, and temperature $>37^{\circ} \mathrm{C}$ accompanied by labor trauma. Infants born with body temperature $\leq 37^{\circ} \mathrm{C}$ are at risk of having neonatal sepsis when it is accompanied by pregnancy complication such as premature rupture of membranes.
\end{abstract}

Keywords: Asphyxia, Baby’s Body Temperature, Birth Weight, Gestational Age, Neonatal Sepsis, Premature Rupture of Membranes

\section{INTRODUCTION}

Neonatal sepsis is one of the major causes of death in newborns, especially at the beginning of birth. Neonatal sepsis can be categorized as early and late neonatal sepsis; $85 \%$ of newborns are infected at the onset of birth, 5\% are infected at 24-48 hours, and the rest occur at 48-72 hours. The incidence of neonatal sepsis varies from 7.1 to 38 per 1000 live births in Asia, 6.5 to 23 per 1000 live births in Africa, and 3.5 to 8.9 per 1000 live births in South America and the Caribbean whereas in the United States and Australian the incidence of neonatal 
sepsis ranges from 1.5 to 3.5 per 1000 live births [1].

Neonatal sepsis and septic shock complications cause an increase in the morbidity and mortality of newborns for years. According to the World Health Organization (WHO), 130 million children are born each year, and about 4 million die each year and $36 \%$ die due to infection. Onehalf of newborn deaths with very low birth weight in the first seven days of life are from severe infections [2].

Based on the results of the 2012 Indonesia Demographic and Health Survey (IDHS), the number of neonatal deaths decreased from 20 per 1000 live births in 2007 to 19 per 1000 live births in 2012 . However, the decline still needs attention because neonatal mortality has contributed to infant mortality by $56 \%$. According to the results of the 2013 Basic Health Research (Riskesdas), the percentage of toddlers (0 - 59 months) with LBW was $10.2 \%$ where the problem of LBW occured in preterm birth and this increased the tendency to complications and infection or sepsis [3]. By looking at the high risk of mortality and various complications attacking in the first week, each newborn should get a standardized examination more often (at least 2 times) within the first week. This step is done to detect early if there is disease or a sign of danger to the neonate so that help can be provided immediately to prevent the occurrence of complications that can cause death [4].

In Indonesia, South Kalimantan Province ranked fifth in the figure of infant mortality in 2005 at 41 per 1000 live births. The data was above national average of 39 per 1000 live births. In addition, infant deaths in 2011, 2012, and 2013 were recorded at 77 cases, 67 cases, and 84 cases, respectively. From the data, an increase in infant mortality is seen in the last two years. The two-thirds of the deaths occurred in the neonatal period (28 days of the first life) due to low birth weight (LBW), prematurity, asphyxia, and neonatal infection (sepsis) [5]. Neonatal mortality can be prevented by early detection of the risks occurring in neonates by conducting standardized examinations at the independently practicing midwives, maternity homes, and hospitals. Ulin Local Hospital of Banjarmasin is the first referral hospital in Banjarmasin that accepts BPJS services for the South Kalimantan Region, the incidence of sepsis in 2013 was 46 cases (1.6\%) of 2904 cases, in 2014 the incidence of sepsis decreased to 21 cases $(0.7 \%)$ of 2877 cases, and in 2015 increased to 81 cases $(14.81 \%)$ of 547 cases so it is necessary to do research on factors related to the incidence of neonatal sepsis.

\section{RESEARCH METHODS}

The method used in this research was a simulation model using Rapid Miner by using 
Algorithm C.45 (Decision Tree) to build a structure of decision tree.

The population in this study was all neonates in the Ulin Hospital of Banjarmasin in 2016, while the sample size was all population of neonatal sepsis by 105 infants and neonates who did not have neonatal sepsis by 105 infants; thus, the number of samples in this research was 210 infants.

The analysis in this research was done to see the level of accuracy using Root Mean Squared Error of classification method C.45 (Decision Tree).

\section{RESULTS}

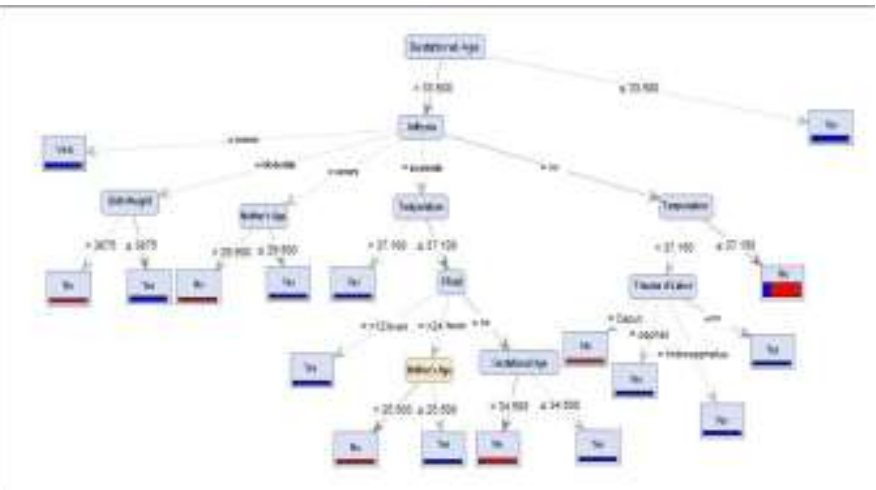

Picture 1 The Result of Decision Tree Algorithm Analysis

The results of analysis using Decision Tree found that the accuracy rate of this research was $80.95 \%$, with the power of the relationship of 0.643 or it can be said strong with the mean error level of 0.401 . It was found that most factors related to the incidence of neonatal sepsis were gestational age and asphyxia. The gestational age $\leq 33.5$ weeks was at risk of sepsis, whereas at the gestational age > 33.5 weeks the sepsis incidence was affected by asphyxia.

In the case of gestational age more than 33.5 weeks with asphyxia, the incidence of neonatal sepsis was influenced by factors of asphyxia types and infant temperature. If asphyxia was severe, it might result in sepsis, whereas if asphyxia was moderate, the occurrence of sepsis might occur if the infant's weight was $\leq 3875$ grams and the body temperature was more than $37^{\circ} \mathrm{C}$. If the infant's body temperature more than $37^{\circ} \mathrm{C}$ could directly cause sepsis. It could also occur if it was accompanied with birth trauma such as Cephal Hematom and Hydrocephalus while for the body temperature $\leq 37^{\circ} \mathrm{C}$ sepsis could occur if it was accompanied by premature rupture of membranes (PRoM). PRoM could cause sepsis when it happened more than 12 hours. For PRoM more than 24 hours, the occurrence of sepsis tended to be influenced by maternal age, ie, less than 25 years.

\section{IV.DISCUSSION}

The results showed that the gestational age of $\leq 33.5$ weeks had a high risk of the occurrence of neonatal sepsis, because infants born at the preterm have a high risk of neonatal infection due to low immunity in the infant. In addition, infants born at the preterm tend to get invasive treatments and procedures that have a chance of infection.

Infants born preterm have lower immune defenses compared to those born at term. Low immunity in infants leads to 
decreased chemotaxis activity and the ability to sync microorganisms. Neonatal sepsis occurring in the preterm has a mortality risk of $60 \%$ while in the aterm it is only $40 \%$ [6].

The study results of the Dini, et al. (2016) in the same hospital as this study mentioned that gestational age had a relationship with the incidence of neonatal sepsis with a $\mathrm{p}$ value of 0.000 and OR of 6.256. This shows the high risk of gestational age that has a risk of having neonatal sepsis six times greater than the low risk gestational age. The study results of Anggraini, et al. (2013) also mentioned that $64.6 \%$ of neonatal sepsis occurred in infants born at gestational age less than 37 weeks $[7,8]$.

This suggests that the gestational age less than 37 weeks affects the occurrence of sepsis because the passive transport of immunoglobulin begins at gestational age of 8-12 weeks via the placenta, and enters the fetal circulation in the infant at the gestational age of 30-40 weeks so that if the infant born at gestational age <37 weeks, it has immature immunity and lacks IgG antibodies against certain bacteria because these antibodies do not cross the placenta from mother to fetal blood until the late pregnancy. Therefore, preterm infants are more susceptible to infection and infection is easy to happen $[9,10]$.

The early onset of sepsis will increase as much as $56 \%$ if the neonate is born with a gestational age of $24-25$ weeks and $9 \%$ if the neonate is born at gestational age $>34$ weeks.
In addition, premature infants are also often carried out invasive measures such as mechanical ventilation, intravascular catheter, and parenteral nutrition, resulting in bacterial transmission in the neonate, and the presence of Patent Ductus Arteriosus (PDA), Necrotizing Enterocolitis and chronic lung disease may increase the risk of neonatal sepsis $[11,17,18]$.

The results of the study found that in addition to the gestational age $\leq 33.5$ weeks, gestational age $>33.5$ weeks could also affect the incidence of neonatal sepsis if the infant had asphyxia at birth. This is in accordance with the results of a study conducted by Roeslani, et al (2013) that infants born from gestational age of $37-42$ weeks have the possibility of sepsis especially in Indonesia. This is because there are deliveries that are still not done at health facilities and not assisted by trained health personals. As for infants born at gestational age > 42 weeks, they may also have neonatal sepsis; this is because post mature infants have a risk of occurring meconium aspiration syndrome and asphyxia. Meconium aspiration syndrome is a respiratory disorder in the newborn caused by the entry of meconium into the lung before or around the time of birth due to stress on the fetus. Meconium is associated with an increased incidence of neonatal sepsis in intra uterine infection because it can alter bacteriostatic properties of amniotic fluid and inhibit immune defenses $[9,12]$. 
Other factors such as complications in labor such as prolonged stage I and stage II may also facilitate germs to enter the respiratory tract resulting in fetus' infection in the uterus and then the infant is born with asphyxia [13].

The condition of neonatal asphyxia at birth can cause neonatal sepsis if the birth weight is $\leq 3875$ grams and the body temperature is more than $37^{\circ} \mathrm{C}$. If the infant is born with low birth weight, the infant will likely have a high risk of neonatal sepsis because the maturity of the organs is not perfect, resulting in complications or even death. The study results of Hasanah, et al. (2016) mentioned that low birth weight will have a greater risk of sepsis 3.607 times than normal birth weight. This is because infants with low birth weight have a chance of becoming infected in the womb causing the impaired uteroplacental blood flow; thus, the transport of various substances required by the fetus including immunoglobulin $\mathrm{G}$ ( $\mathrm{IgG}$ ) which play a role as body's defenses in the early life is disrupted [14].

Low birth weight not only occurs in preterm delivery but also in at term delivery; this is due to impaired growth of the fetus so that the infant is born smaller at the gestational age while the baby with normal weight in the first week of life will have weight loss due to breastfeeding problems. In addition, infant born with normal birth weight with complications of PRoM also need attention because they are at risk of neonatal sepsis although not directly, especially if the infant has hypothermia ( $\leq 37$ o $C)$. Therefore, monitoring should be further required if the infant is born with PRoM complications and hypothermia as it may increase the risk of neonatal sepsis. The study results of Suwiyoga, et.al (2007) stated that the risk of early onset of sepsis in PRoM $<12$ hours is 1.5 times, $>12-18$ hours is 7 times, and $>18$ 24 hours is 9 times. The results of this study showed that in addition to PRoM $>12$ hours, PRoM >24 hours also had risk of neonatal sepsis if the maternal age $<25$ years. This is in accordance with the results of Lestari's study (2012) that the percentage of patients with neonatal sepsis based on the characteristics of maternal age in the age $<20$ years is $5.5 \%, 20$ 35 years is $74 \%$ and > 35 years is $20.4 \%$. Maternal age cannot be a direct risk factor for neonatal sepsis because from maternal age the complications experienced during pregnancy and labor will be reviewed $[15,16]$.

In addition to the factor of labor complications, ie, PRoM, infants born without complications also need attentions so that monitoring and supervision should always be performed. When the rooming-in is done simultaneously to the infant's care, infants can easily lose body's heat if they are not treated properly by the mother and family. Inadequate care such as not maintaining the warmth of the infant will cause the loss of heat so the infant is easy to experience hypothermia. The symptoms of hypothermia are often not known by the mother or family; 
however, the condition of hypothermia is often known if the infant shows signs of danger such as respiratory disorders and cyanosis, or when the infant look reluctant to be breastfed.

The increased body temperature in infants $\left(>37^{\circ} \mathrm{C}\right)$ is a symptom of infection of a disease especially in infants with labor trauma such as Cephal Hematom and Hydrocephalus so that the possibility of neonatal sepsis occurs. Therefore, infants born with labor trauma need to be paid attentions in order to avoid infection. This is consistent with the results of Simbolon's study (2008) that the incidence of neonatal sepsis according to labor history shows that the incidence of neonatal sepsis can be 2.142 times greater in infants born with treatments than in normal-born infants [1].

\section{CONCLUSION}

Based on the results of research and discussion it can be concluded that the most influential factor on the incidence of neonatal sepsis in hospitals. Ulin Banjarmasin The year 2016 is 33.5 weeks gestational age, 33.5 weeks' gestation can be a risk factor for neonatal sepsis if the baby is born with asphyxia complication, birth weight $\leq 3875$, and baby temperature $>37^{\circ} \mathrm{C}$ accompanied by labor trauma while temperature The baby's body $\leq 37^{\circ} \mathrm{C}$ also has an infant's risk of having neonatal sepsis if accompanied by a pregnancy complication is premature rupture of membrane therefore needs attention and alertness to all newborns either born months or less months because neonatal sepsis is likely to occur if maternal delivery and pregnancy are accompanied by complications.

\section{ACKNOWLEDGMENTS}

We deliver our gratitude to to the Head of Sari Mulia Health School and the Director of Sari Mulia Midwifery Academy of Banjarmasin who have provided supports in conducting this research and to the Director of Ulin Local Hospital of Banjarmasin who has facilitated the research site.

\section{REFERENCES}

[1].Simbolon, Demsa. Faktor Risiko Sepsis pada Bayi Baru Lahir di RSUP Curup Kabupaten Rejang Lebong. 2008. Politeknik Kesehatan Bengkulu. Diakses tanggal 29 Oktober 2016

[2].Silveira, Rita de Cassia, Clarice Giacomini, Renato Soibelmann, Procianoy,. Neonatal Sepsis and Septic Shock: Concepts Update and Review. 2010. Review Article

[3].Badan Pusat Statistik, 2013. Survei Demografi Kesehatan Indonesia Tahun 2012 . chnrl.org/pelatihandemografi/SDKI-2012.pdf Diakses tanggal 29 Oktober 2016

[4].Sitohang, Vensya, 2014. Profil Kesehatan Indonesia Tahun 2013. Kementerian Kesehatan Republik Indonesia: www.depkes.go.id/.../profil-kesehatanindonesia/profil-kesehatan-indonesia

Diakses tanggal 29 Oktober 2016

[5].Dinas Kesehatan, Provinsi Kalimantan Selatan. 2014. Data Seksi Kesehatan Keluarga Dinas Kesehatan Provinsi Kalimantan Selatan. Banjarmasin.

[6]. Aminullah A. Sepsis pada Bayi Baru Lahir. Dalam: Kosim, MS., Yunanto, A., Dewi, R. et al. Buku Ajar Neonatologi. 2008. Jakarta: Badan Penerbit Ikatan Dokter Anak Indonesia. 
[7].Dini, Fitri Nur, Andayani, Puji, Rosida, Lena. Hubungan Antara Masa Gestasi dan Kejadian Sepsis Neonatorum di RSUD. Ulin Banjarmasin Periode Juni 2014 Juni 2015. 2016. Universitas Lambung Mangkurat: Berkala Kedokteran Vol.12, No.2, Sep 2016:175-185

[8]. Anggraini A, Sumadiono, Wandita Setya. Faktor Risiko Kematian Neonatus dengan Penyakit Membran Hialin. 2013. Sari Pediatri: Vol.15, No.2, Agustus 2013

[9]. Goldenberg RL, Culhane JF, Iams JD, Romero R. Epidemiology and Causes of Preterm Birth. 2008. Lancet. 2008;371: 75 -84 .

[10]. Apriliana E, Rukmono P, Erdian DN, Tania F. Bakteri penyebab Sepsis Neonatorum dan Pola Kepekaannya terhadap Antibiotika. 2013. Seminar Nasional Sains \& Teknologi V Lembaga Penelitian Universitas Lambung Mangkurat.

[11]. Chu A, Hageman J, Schreiber M, Alexander K. Antimicrobial Therapy and Late Onset Sepsis. NeoReviews. 2012;13(2): 94 - 9

[12]. Roeslani RD, Amir I, Nasrulloh MH, Suryani. Penelitian awal: Faktor Risiko pada Sepsis Neonatorum Awitan Dini. Sari Pediatri: 2013;14(6):368-68

[13]. Kosim MS, Yunanto A, Dewi R, Sarosa GI, Usman. 2014. Buku Ajar Neonatologi Edisi Pertama. Jakarta: IDAI

[14]. Hasanah NM, Lestari H, Rasma. Analisis Faktor Risiko Jenis Kelamin Bayi, BBLR, Persalinan Prematur, Ketuban Pecah Dini, dan Tindakan Persalinan dengan Kejadian Sepsis Neonatus di Rumah Sakit Bahteramas Provinsi Sulawesi Tenggara. 2016.. Fakultas Kesehatan Masyarakat Universitas Halu Oleo.

[15]. Suwiyoga K., Budayasa, A.A. Raka. Peran Korioamnionitis Klinik, Lama Ketuban Pecah dan Jumlah Periksa Dalam pada Ketuban Pecah Dini Kehamilan Aterm terhadap Insiden Sepsis Neonatorum Dini. 2007. Cermin Dunia Kedokteran, Vol. 34, No. 05/158.
[16]. Lestari, Dewi Ayu. Karakteristik Penderita Sepsis Neonatorum Rawat Inap di RSUD Dr. Pirngadi Medan. 2012. Tesis: Fakultas Kesehatan Masyarakat USU http://www.google.co.id/url?sa=t\&rct=j $\& q=$ penelitian+lestari+2012+tentang+se psis\&source Diakses tanggal 02 Agustus 2017

[17]. Leal Y, Alvarez Nemegyei J, Velazquez J, Rosado Quiab U, Diego Rodriguez N, Paz Baeza E. Risk Factors and Prognosis for Neonatal Sepsis in Southeastern Mexico: Analysis of Four Year Historic Cohort Follow Up. 2012. $J$ Biomedcentral. www.biomedcentral.com/14712393/12/48 Diakses tanggal 2017, 02 Agustus

[18]. Wynn James L and Wong Hector R., Pathophysiology and Treatment of Septic Shock in Neonatus. 2010. Clin Perinatol: Duke University, Departement of Pediatrics Division of Neonatal Perinatal Medicine. 